\title{
The Role of the State in the Latin Countries: Similarities and Differences. Why and How Educational Systems' Organization Can Be Affected
}

\section{Eleftheria Argyropoulou}

Panepistimio Kritis - School of Education (Greece)

doi: 10.7358/ecps-2015-011-argy

eleftheria@iacm.forth.gr eargirop@edc.uoc.gr

\section{IL RUOLO DELLO STATO NEI PAESI LATINI: ANALOGIE E DIFFERENZE. PERCHÉ E COME IL SISTEMA ORGANIZZATIVO EDUCATIVO PUÒ ESSERE INFLUENZATO}

\section{Abstract}

In terms of organizational structure, educational systems are closely related to the administrative systems of their respective countries. Looking at Southern European countries (and namely Spain, Italy, Portugal, Greece and, to a lesser degree, France) from a comparativist stance, one can see a number of common elements characterizing their administrative systems. Their main common feature is the lack of decentralization in educational decisionmaking, a fact that makes them rank very low in OECD assessments. This paper attempts to identify the reasons and factors that led Southern European countries to this position by examining their laws and their administrative and educational system peculiarities. The type of legal system and type of state in Southern Europe offer an alternative analysis platform when researching the similarities and differences of educational systems. This comparativist view opens up a broad research field: it can support networking and help exchange ideas on policy and practices with a view to improving education and the future of our children.

Keywords: Administrative system, Educational system, Law, Southern European countries, State. 


\section{INTRODUCTION}

The multi-cultured and multi-centered character of modern western societies has facilitated the development of supranational independent or semiindependent "fields», organizations of legal status such as the World Bank, the International Monetary Fund or the European Union. The state or nonstate supranational legal systems seem to interact and depend on each other (Deligianni-Dimitrakou, 1997).

Over the last five years, in the course of the deepening economic crisis all over the world, the states of Southern Europe, and mainly Greece, have been accused by supra-national organizations of being the weak links in the economic growth of Europe, due to the inconsistencies in their public sector expenditures. According to the supporters of this view, this is due to their ineffective public administration structure and public finance governance. They also argue that the results of this instability and malfunction are seen in all aspects of societal institutions, including education.

\section{THE AIM OF THIS PAPER}

The structure and morphology of educational systems are affected by a great number of factors either inherent to the structure of the state they are part of, or external, that is, outside the sphere of the state. For example, the geomorphology of a certain country may affect the way the state services are structured. Or the state's history and culture form dominant variables of the law and justice system and its civil services. From a broader systemic point of view, the institution of education cannot be seen outside society; that is, it forms a subsystem of a wider socio-politico-economic system which is the state itself. As such, it is intrinsically associated with all the other social institutions that form the state. Specialists in the organization, management and leadership in education should be able to trace, identify, evaluate and, finally, make good use of these factors when designing and implementing policies. In this paper we examine two factors that contribute to the formation of the state profile from an organizational point of view: the type of legal system and the specifications of the state administrative system in the countries of Southern Europe. Our short analysis works towards this direction by trying to answer the following questions:

a. Are there any common characteristics among the states of Southern Europe?

b. Which factors are or have been critical to the formation of these common characteristics? 
c. How do these characteristics affect the structure of the educational systems?

d. Are these characteristics good or bad; who can judge and with what criteria?

e. What possibly lies behind these judgments and criticisms?

\section{Definitions}

Before we proceed with our discussion, it is necessary to define what we mean by the term states of Southern Europe. Southern Europe is usually identified with states in the Euro-Mediterranean Region - Greece, Italy and Spain; but, in terms of economic and/or political analysis, this region can be extended to other countries sharing similar socio-political and economic problems, although not being in the Mediterranean, such as Portugal, or countries which are partly on the Mediterranean coast, but do not have these problems, such as France. Minor Mediterranean countries, such as Cyprus and Malta, had not been dynamic actors in the scene until recently. Hence, emphasis on the role of the state will be given mostly with regard to the three major Mediterranean countries, Italy, Greece and Spain, with cross-national references and comparisons with Portugal and France. One could argue that since France is a large country with a varied regional profile, it cannot be included in this analysis. However, two main reasons permit the inclusion of France: (a) a large part of the country overlooks the Mediterranean and thus has a considerable number of common Mediterranean characteristics (in terms of race, ethnicity and history); (b) concepts and ideas in France over the last three centuries have been in continuous interaction with those developed in the other countries under discussion. Hence, one can trace a constant cultural dialogue and a relativeness and exchange among all five countries concerned.

\section{LIMITATIONS}

The state can be analyzed with regard to all its organizational elements, functions and implications (social care provision, security, finance, defense, internal and external relations, etc.) but this is not the case here. In this paper, the role of the state is examined only in terms of administration and law parameters. Public administration's organizational structure and administrative law are crucial for the infrastructure of the educational system's organization. Although state finance is also important for the structure and maintenance of social systems, it is not included in this short and time-restricted analysis. 


\section{METHOD}

This paper draws upon comparative law and administrative law specialists' work from various national contexts, as well as from OECD and EU statistical data. The method chosen for the purposes of this paper is that of the descriptive analysis (Wolcott, 1994) of what the various (mostly bibliographical) data tell us about the organizational characteristics of the five states concerned. We will attempt to analyze the information provided by the data, identify key factors and possible relations among them, and interpret the findings so as to reach an understanding of the peculiarities underpinning the role of the state in the aforementioned countries.

\section{EVIDENCE ON DECISION-MAKING IN EDUCATION}

\subsection{OECD data on education}

It could be argued that many of the OECD indicators in education (2012) can reflect the way educational systems are structured. In the discussion of the role of the state, however, the most appropriate of these indicators seems to be the D6 (ibid., pp. 500-518) measuring the degree of freedom in decision-making in education. The indicator describes the centrality or non-centrality of educational decisions by analyzing four variables: organization of instruction, personnel management, planning and structure of the educational system, and resource management (see Table 2, below). According to Table D6.1 (ibid., p. 500) all five countries are classified «below OECD average» due to the high degree of centralization in educational decisions (see Table 1, below). The criterion for this classification is as follows (taken from the OECD report): since the early 1980's a key aim of educational reform has been to place more decision-making authority at lower levels of the education system. The most common reasons to decentralize decision-making are increased efficiency and improved financial performance.

This statement, in a passive voice, does not reveal the agent of the sentence: whose aim is this and why? Decentralization is the de-constructing of the principal role of the state as the provider of social services; in deconstructing the state, decision-making goes beyond the idea of the social state and moves further on to the idea of a more liberal type of state. 
Table 1. - D6 general: Decision-making in the educational systems under examination.

Source: OECD, 2012.

Data: 2011, from lower secondary schools.

\begin{tabular}{|c|c|c|c|c|c|}
\hline Country & $\begin{array}{c}\text { Position } \\
\text { IN OECD } \\
\text { CLASSIFICATION }\end{array}$ & $\begin{array}{c}\text { SCHOOL } \\
\text { LEVEL }\end{array}$ & $\begin{array}{l}\text { LOCAL } \\
\text { LEVEL }\end{array}$ & $\begin{array}{l}\text { REGIONAL } \\
\text { LEVEL }\end{array}$ & $\begin{array}{c}\text { Central } \\
\text { GOVERNMENT } \\
\text { LEVEL }\end{array}$ \\
\hline Italy & 19 & $40 \%$ & $2 \%$ & $18 \%$ & $40 \%$ \\
\hline France & 21 & $+/-30 \%$ & - & $+/-30 \%$ & $+/-30 \%$ \\
\hline Spain & 25 & $+/-23 \%$ & - & $+/-17 \%$ & $60 \%$ \\
\hline Portugal & 27 & $+/-31 \%$ & - & - & $79 \%$ \\
\hline Greece & 35 & $+/-5 \%$ & $+1-5 \%$ & $12 \%$ & $78 \%$ \\
\hline
\end{tabular}

Table 2. - D6 variables: Decentralized levels of decision-making (priority ranking).

Source: OECD, 2012.

Data: 2011, from lower secondary schools.

\begin{tabular}{|c|c|c|c|c|c|}
\hline Country & Position & $\begin{array}{l}\text { ORGANIZATION } \\
\text { OF INSTRUCTION }\end{array}$ & $\begin{array}{c}\text { PERSONNEL } \\
\text { MANAGEMENT }\end{array}$ & $\begin{array}{c}\text { PlanNING } \\
\text { AND STRUCTURE }\end{array}$ & $\begin{array}{c}\text { RESOURCE } \\
\text { MANAGEMENT }\end{array}$ \\
\hline Italy & 13 & $\begin{array}{l}\text { School }[90 \%]- \\
\text { central }[10 \%]\end{array}$ & $\begin{array}{l}\text { Regional- } \\
\text { central }\end{array}$ & $\begin{array}{l}\text { Central-school- } \\
\text { regional }\end{array}$ & $\begin{array}{l}\text { Central-school- } \\
\text { local-regional }\end{array}$ \\
\hline France & 22 & $\begin{array}{l}\text { School }[75 \%]- \\
\text { central }[10 \%]- \\
\text { regional }[5 \%]\end{array}$ & $\begin{array}{l}\text { Central- } \\
\text { regional }\end{array}$ & $\begin{array}{c}\text { Central-school- } \\
\text { regional }\end{array}$ & $\begin{array}{c}\text { Regional }[80 \%]- \\
\text { central- } \\
\text { school }\end{array}$ \\
\hline Spain & 24 & $\begin{array}{l}\text { School }[76 \%] \text { - } \\
\text { central }[10 \%]- \\
\text { regional }[4 \%]\end{array}$ & $\begin{array}{l}\text { Central- } \\
\text { [regional] }\end{array}$ & Central-regional & $\begin{array}{l}\text { Central- } \\
\text { regional- } \\
\text { school }\end{array}$ \\
\hline -..--_-.-.- & $\begin{array}{l}\text { OECD } \\
\text { average }\end{array}$ & $\begin{array}{l}\text { OECD } \\
\text { average }\end{array}$ & $\begin{array}{l}\text { OECD } \\
\text { average }\end{array}$ & $\begin{array}{l}\text { OECD } \\
\text { average }\end{array}$ & $\begin{array}{l}\text { OECD } \\
\text { average }\end{array}$ \\
\hline Portugal & 33 & $\begin{array}{l}\text { School [58\%] - } \\
\text { central }[42 \%]\end{array}$ & $\begin{array}{l}\text { Central- } \\
\text { school }\end{array}$ & Central 100\% & $\begin{array}{l}\text { Central- } \\
\text { school }\end{array}$ \\
\hline Greece & 35 & $\begin{array}{c}\text { Central }[58 \%] \text { - } \\
\text { regional }[31 \%] \text { - } \\
\text { school }[6 \%]- \\
\text { local }[5 \%]\end{array}$ & $\begin{array}{c}\text { Central [70\%] - } \\
\text { local }[30 \%]\end{array}$ & Central 100\% & $\begin{array}{l}\text { Central- } \\
\text { school- } \\
\text { local }\end{array}$ \\
\hline
\end{tabular}


In this linear movement form social to liberal, where do the Southern Europe states actually stand? All five countries rank below the OECD average, in various positions, though. We will show how the centralization tendencies in Southern Europe are associated with the deep structure of the state and the "Mediterranean" social thinking.

\subsection{The European Union (EU) data on education}

The European Union, via the Education, Audiovisual and Culture Executive Agency ${ }^{1}$ (EACEA), also has an Indicator System (similar to that of the OECD) for the evaluation of education systems. Eurydice indicators (2012) evaluate school autonomy in primary and secondary education using slightly different variables: (a) managing human resources (selecting school heads, determining duties and responsibilities for school heads, selecting new teachers, substituting teachers or dismissing teachers, determining duties and responsibilities for teachers, etc.); (b) managing financial resources (use of public funds, etc.); (c) teaching and learning (curriculum, textbooks, etc). Regarding the five countries concerned, results from the Eurydice indicators show a resemblance to those from the OECD indicators. In most cases, expenditure on teaching staff tends to be determined centrally and teachers are often employed centrally or regionally; there is also a variety of approaches to determine the curriculum content. Only in the case of managing financial sources, especially the ones for the operation and maintenance of schools, does there seem to be relative school autonomy across Europe. Eurydice data do not show an average, a threshold level, as the one provided by the OECD indicators. Consequently, there is no explicit classification of the national education systems as centralized or decentralized. Levels of autonomy are presented in different colours in collective descriptive tables (Eurydice, 2012, pp. 49-58) including all participating countries. There are only implications about the benefits of school autonomy and, hence, of the decentralization of the education systems.

1 The Education, Audiovisual and Culture Executive Agency, working under the auspices of the European Commission, gathers education data via the major database Eurydice/ Eurostat and publishes the key data on education on an annual basis. Eurydice data come from Eurostat collection exercises. In the 2012 edition the data cover the period 2007-2012 and they come from the 33 European countries involved in the Eurydice network taking part in the Lifelong Learning Programme. 


\section{The nature of The Legal systems in Southern Europe}

\subsection{A typology of legal systems}

Why are we examining law? Law is the expression of culture; it is associated with the specific historical, social, political, psychological and economic environment in which it has been developed. From this point of view, each national legal system is unique and different from any other. Comparing state systems means understanding state systems, not scaling them. The purpose of comparing and understanding law is the emergence of the cultural elements which compose the mentality of a given culture (Legrand, 1999).

According to Montesquieu (1872), among various factors which contribute to this differentiation, the most prominent are: the geographical position, the climate and the economy of a certain state. However, differences and similarities between these factors can form the basis for a macro comparison of legal systems. The results of such a comparison help to get to know and understand the law of other states we are in interaction with.

Many criteria have been used for the sake of comparison; hence, we have a variety of typologies. The one we are applying here is that of the origin of the legal systems, as it entails geographical and historical dimensions. According to Glasson, as quoted by Moustaira (2012), it is the oldest and the commonest basis for legal macro-comparisons. Based on this criterion, we can identify two major types of legal systems: (a) Neo-Roman Law, or Roman-Germanic Law or Civil Law; and, (b) Common Law or Case Law. Civil Law ${ }^{2}$ systems trace their history back to Roman Law and the so-called Napoleonic Code, while Common Law systems trace their history back to Old England ${ }^{3}$. The main difference between the two systems lies in the way

2 The term civil law comes from English legal scholarship (actually, from the Latin term jus civilis as opposite to jus gentium) and is used in English-speaking countries to include various Roman legal traditions (reference). In this paper we will use the term Neo-Roman Law. It is the most widespread system of law in the world, in force in various forms in about 150 countries. Colonial expansion (mainly of countries, such as Spain and Portugal) spread Roman Law to a much of Latin America and to some parts of Asia and Africa.

3 Common Law has its roots in England, where it originated in the Middle Ages. It goes back to the reign of Henry II of England (circa 1150-1160), when the King's judges followed each other's decisions to create a unified common law throughout England. Moreover, there were the King's itinerant judges, who travelled from town to town dispensing the King's justice. The term common law was used to describe the law held in common between the circuits (of their itinerary) and the different stops in each circuit. It is also found in countries that trace their legal heritage to England as former colonies of the British Empire. One third 
justice is delivered in courts ${ }^{4}$, that is, how jurisdiction is made: in the NeoRoman systems the primary source of law is the Code (which is a systematic and coherent collection of interrelated articles, arranged by subject matter in some pre-specified order, explaining the principles of law, rights and entitlements, and the function of legal mechanisms), while great weight is placed on court decisions, which are considered «law» with the same force of law as statutes in the Common Law systems. By contrast to Neo-Roman courts, Common Law courts have - so far - had the authority to make law where no legislative statute exists. The strength of judicial opinion in Common Law systems has been considered «a significant contributor to the robust commercial systems in the United Kingdom and United States» (Yeo Tiong Ming, 2006), a foundation for commercial economies and the "path [...] for the man in the future» (Holmes, 1897). Moreover, it could provide solutions to cases where there was no precedent or no statutory provision.

Not all European countries share the same type of legal systems. More specifically, the UK (except Scotland ${ }^{5}$ ), Ireland and Cyprus have Common Law, while the rest of Central Europe follows Neo-Roman Law. On the other hand, Roman Law and the Napoleonic Code had no influence on Scandinavian legal systems. Although based on the old German law, these systems developed on their own. It is worth mentioning that these systems had the older codifications (compared to those of Central and Southern Europe) and that they are constructed on the principle of simplicity (Moustaira, 2012).

\subsection{Neo-Roman Law and the states of Southern Europe}

What we call Roman Law is actually the content of the codifications ordered by the Byzantine Emperor Justinian I (who reigned in 527-565). This first layer of law was covered by later codifications; Napoleon ordered a codification in the early nineteenth century (1804), while a little later, in the beginning of the 20th century, the German Urban Code (1900) appeared. These two codes influenced the formation of legal systems of the modern states of Central and Southern Europe. Thus, France follows the Napoleonic Code, Spain and Italy are strongly rooted in the Napoleonic

of the world's population (approximately 2.3 billion people) live in countries where there is Common Law jurisdiction or mixed (with Roman Law) type legal systems.

4 Moustaira $(2012$, p. 66), however, argues that this distinction is not accurate, as the British law follows many different paths, not only that of Common Law. Various legal practices, traditions and values-ideas are intertwined in the juridical process. Apart from the principle of precedent, the principle of equity is a strong element of this type of law.

5 Scotland has a bijuridicial or mixed system. 
Code, while Greece and Portugal seem to be widely influenced by the German Urban Code.

In Southern European countries there is a strong attitude towards «being lawful, keeping the letter of the law»; such an attitude seems natural in a context of codifications where there is a "prescribed" penalty for any crime and where everything falls into a certain categorization. Consequently, the role of the state, as (perhaps) the sole source of producing and maintaining the law, is particularly powerful. Dogma and technicality characterize the state law producing mechanisms, which, in their turn, use - in excess - vague and theoretical language. This again leads to the production of new statutory guidelines to explain the previous ones, thus resulting in a plethora of rules which are very easy to be misunderstood or misinterpreted. Given a rather old fashioned bureaucratic state structure, this vicious cycle reinforces the almightiness of the state and, at the same time, promotes the idea that someone can be "secure" only within the shield of the state; only «within the state», not outside it.

\section{THE NATURE OF PUBLIC ADMINISTRATION IN SOUTHERN EUROPE}

Sotiropoulos (2007) maintains that in the last quarter of the 20th century a particular type (ideotype) of state was developed in Southern Europe, due to certain political factors residing in Southern European countries:

- A more or less common recent historical background in the majority of Southern European countries: during the latter half or even the last quarter of the 20th century there were dictatorships in Greece, Spain and Portugal, while Italy had a dictatorship earlier (1920s, 1930s and early 1940s). It is worth mentioning that dictatorship abolishment coincides in Portugal (April 1974), Greece (July 1974) and Spain (1975).

- All these national systems started to strive for democratization and modernization of their administration according to new managerial approaches and the introduction of new technologies. In doing so, they felt a strong external pressure to align with the rest of Europe in order to achieve the desired European integration and, at the same time, to be able to compete with more developed countries in a globalised economic context.

- The Southern European states adopted the Weberian model of organizational structure rather late compared to other states of western or Northern Europe. However, this adoption was never full or complete and mainly concerned external characteristics of the administrative system, without going deeper in terms of efficiency, effectiveness and responsiveness to social needs. 
- The Southern European states tried hard to introduce decentralization in their administrative systems; but, the degree and the type of decentralization differs dramatically from country to country.

These factors in turn resulted in the formation of attitudes and mentalities among the public administrators and in society. Civil servants did not realize their own role - that they were there to serve people; they were often arrogant, rude and corrupt. The people, society, felt offended, dissatisfied with the service provided, frustrated by the consequent delays, malfunctions and inefficacity of the administration. Thus, «a peculiar political top-down clientelism was created to serve the interests of the superior levels of the administrative mechanism while - at the same time - another bottom-up set of relations between the state and the people was unofficially established; the latter was striving to absorb the social turbulence by employing people to surplus posts of the public sector» (Sotiropoulos, 2007, p. 184).

On the other hand, the state (and what this may represent) tried to remedy the inefficacity by introducing new administrative laws and regulations. This was supposed to help the transition to a modernized form of administration but, in fact, led to deeper bureaucratic structures with more central power and less autonomous peripheral decision-making.

However, it is very important to note that there are significant differences ${ }^{6}$ among Southern Europe states. These differences reside in factors associated with:

- The way the political system evolved in each country: there may be similarities in Southern Europe's political history of the latter half or even last quarter of the 20th century, but the history of each state before or after that period is not the same. In Spain there is still a royal family, while royalty is out of the question in Greece. At the same time, both countries present similarities as they had had a social government for a long period (from the beginning of the 1980's).

- The degree of industrialization played a crucial role in their development; for example, Italy and Spain had larger industrial units than Greece or Portugal. Italy reached a high degree of economic development compared to the others.

- As already mentioned, the degree and type of decentralization differ dramatically from country to country. Spain, for example, became a quasifederation of 17 communidades autonomas, 17 minor divisions of public administration with a wider range of independence in decision-making. The same applies to the 20 regioni (regions) of Italy with their own local

6 Of course, this is not an exhaustive list of differences but an indicative one to show that each country kept their own political profile. 
government, sometimes of different political orientations. Greece and Portugal, however, have remained faithful to the central government model.

- France, on the other hand, seems to have developed according to various patterns of industrialization. An economically strong state, at least until recently, it has been self-sufficient and dependent on its own production sources. Moreover, due to its geographic position and vast area, compared with the other four countries, it brings together various characteristics of both Central-North and Southern Europe. Decentralization patterns, though, seem to resemble the rest of the Southern European states, except for its regional authorities, which are very strong. Greece often seems to "copy» the French decentralization pattern and the state service mechanisms, with an emphasis on control and hierarchical promotion tactics. This resemblance is also obvious in the structure of the education services.

\section{Conclusions}

How are the legal and administrative systems associated? How is education associated with the type of legal system? Public administration is determined by and based on administrative law. Administrative law constitutes a sub-codification of a civil legal system. Education is a society sector and the state has to provide for it. Provision is realized via Educational Law which is in turn a sub-category of administrative law (Mihopoulos, 2002; Champagne, 20037).

The short analysis attempted above can provide answers to the discussion questions asked at the start of this article. The nature of public administration as described in the previous section answers the second of the questions. Regarding questions (a) and (c), it is argued that the Southern European countries share common characteristics to a considerable degree. More specifically, most education provision is in the hands of the state, public/state education, while only a small percentage is provided by the private sector (private schools, church schools, etc.). Teachers are appointed and paid - more or less - centrally (see Table 2 above), a fact that makes them civil servants. As such, they act according to public administrative law regulations, often "prescribing» attitudes and behaviors at the school level. Thus, teachers may share common features with other civil servants, but not to the same extent, as the civil servant office is suppressed by the pedagogical and humanistic ideals governing their profession. The same - more or less - applies to the

7 Champagne quotes article L. 121-4: «La loi reunit tous les établissments pour definer leurs mission» (The law reunites all establishments in order to define their mission). 
provision and delivery of the curriculum. As it is «national», it presupposes a central design and centrally appointed regulations for implementation. In this aspect, OECD suggestions towards decentralization initiatives are in conflict with national/local policies; in fact, they contrast with national/local attitudes towards the social/socialistic provision of education and cause policy debates.

There is a wide range of answers one can provide to questions (d) and (e). Answers depend on the criteria or the paradigm one may use to assess the "political behaviors» in Southern European countries. For example, the criterion of school autonomy is promoted within the market-oriented paradigm for school financial independence. This specific criterion has been employed by international organizations with a wide neoliberal scope. As per this criterion, the Southern European countries show a deficit; accordingly, they rank very low in Tables 1-2 above. On the other hand, if a neo-Marxist paradigm had been used, promoting the social welfare State model and an education system totally dependent on State funding, then the same countries would have been higher up in the ranking.

\section{Epilogue}

Societal and political differences originate in different historical backgrounds and contextual factors. However, stressing the differences among nations does not seem to be the right approach to solve the problems, but to deepen them. Policies should recognize the necessity of the acceptance of diversity and - at the same time - equity and equality. To gain an understanding of diversity, it is necessary to identify and to get to know the deeper roots of similarities and differences among states and systems.

The type of legal system and the type of state in Southern Europe offer an alternative analysis platform when researching the similarities and differences of education systems. This comparativist stance opens up a broad research field and can support networking and help the exchange of ideas on policy and practice with a view to improving education and the future of our children.

\section{REFERENCES}

Champagne, P. (2003). L'organization scolaire et universitaire. Paris: PUF.

Deligianni-Dimitrakou, Ch. (1997). Introduction to the comparative law. Athenai: Sakkoulas. 
Eurydice (2012). Key data on education 2012. Eurostat.

Holmes Jr., O. W. (1897). The path of the law. Harvard Law Review, 10(8), $457-$ 469. doi: 10.2307/1322028. http://www.gutenberg.org/ebooks/2373.

Legrand, P. (1999). Droit comparé. Paris: PUF.

Massey, D. (1993). Power-geometry and a progressive sense of space. In J. Bird, B. Curtis, T. Putnam, G. Robertson, \& L. Tickner (Eds.), Mapping the futures: Local cultures, global change (pp. 60-70). London: Routledge.

Mihopoulos, A. (2002). Educational law. Athenai: Grigoris.

Montesquieu, Charles de Secondat, baron de (1872). L'ésprit des lois. Paris: Librairie de Firmin Didot (e-book from Harvard College Library, by exchange).

Moustaira, E. (2012). Comparative law. Athenai: Nomiki Bibliothiki.

OECD (2012). Education at a glance. Indicators (D6). Paris: OECD.

Sotiropoulos, D. (2007). State and reform in modern Southern Europe: Greece, Spain, Italy, Portugal, Athens. Athenai: Potamos.

Yeo Tiong Min (2006). A note on some differences in English law, New York law, and Singapore law. http://www.singaporelaw.sg/content/SomeDifferences.

\section{Riassunto}

In termini di struttura organizzativa, i sistemi educativi sono strettamente collegati ai sistemi amministrativi dei rispettivi Paesi. Guardando i paesi del Sud Europa (vale a dire la Spagna, l'Italia, il Portogallo, la Grecia e la Francia, in misura minore) secondo una analisi comparata, si possono vedere un certo numero di elementi comuni che caratterizzano $i$ vari sistemi amministrativi. Una principale caratteristica comune è la mancanza di decentramento nel processo decisionale educativo, un fatto che posiziona questi Paesi in un bassissimo livello nelle valutazioni dell'OCSE. Questo articolo cerca di individuare le ragioni dei fattori che hanno spinto i Paesi dell'Europa meridionale a queste decisioni esaminando le particolarità dei loro sistemi legali, amministrativi ed educativi. Il tipo di sistema giuridico e il tipo di concezione dello Stato nei Paesi del Sud dell'Europa offrono una piattaforma di analisi alternativa quando si ricercano le somiglianze e le differenze dei sistemi educativi. Questa analisi comparata apre un campo di ricerca ampio, in grado di supportare reti di relazioni e aiuti nel confronto delle idee sulla politica e la prassi che mirino al miglioramento dell'istruzione e del futuro dei nostri figli.

Parole chiave: Analisi comparata, Paesi dell'Europa meridionale, Sistema amministrativo, Sistema educativo, Sistema legislativo, Stato. 